\title{
Parental Motivation and Achievement
}

\author{
Jerald C. Moneva \\ Department of Education-Mandaue City Division \\ Mandaue City, Cebu, Philippines \\ Tel: +63908-927-3038Ｅ-mail: freezingfire1979@gmail.com
}

\author{
Linive C. Japos \\ Jagobiao National High School \\ Mandaue City, Cebu, Philippines \\ Tel: +63920-383-8164Ｅ-mail: LiniveJapos@gmail.com
}

\author{
Rosalie L. Ohayas \\ Cebu City, Philippines \\ E-mail: rosalieohayas001@deped.gov.ph
}

Received: February 9, 2020 Accepted: March 11, 2020 Published: April 2, 2020

doi:10.5296/ijssr.v8i2.16790 URL: http://dx.doi.org/10.5296/ijssr.v8i2.16790

\begin{abstract}
The motivation that parents provide to their students can have a significant impact on achievements in school. The study intends to assess the level of parental motivation and achievers of junior high and senior high. Parental motivation is given by the parents towards their students to make them work harder or being determine their studies that leads them to have better achievements in school. The checklist is made up of two parts, parental motivation and the level of achievement. The research was a quantitative correlation design. The respondents are the achievers from junior high and senior high and consist of overall respondents of 145 respondents. To treat the data, the researcher used a statistical test the weighted mean, chi - square to determine the relationship of the two variables. The study revealed that parents do not always provided a motivation to their students most of the parents sometimes give a motivation to their student. However, the achievements of students are still in high level. The achievements of students do not always depend on their parents'
\end{abstract}




\section{Macrothink}

International Journal of Social Science Research

ISSN 2327-5510

motivation yet their achievement is based on their personality of being determined and consistent in their studies. Not all the time that the motivation of parents can enhance the educational achievements of students.

Keywords: achievement, achievers, parental motivation, students 


\section{MInstitute ${ }_{\text {Mnk }}^{\text {Macrothink }}$}

\section{Introduction}

\subsection{Rationale}

Parents provide proper motivation can help their students being productive in school. Motivated students can give pleasure to their parents and persistence in their studies. They tend to give more effort which required time in their studies. However, the achievements of the students depend on how their parents motivate them.

Students need motivation from their parents to have a strong desire in their studies. They give more effort in every presentation in order to be achievers in school. Furthermore, it is important for parents to keep their students motivated. In particular, most top learners are good in all subjects. Even though they have failure sometimes but they did not give up yet. They give their best in school. Students are very active in doing their task and ask questions if there are things they do not understand about the discussion that's why they have the highest scores and grades. However, some of the top students are not fully motivated by their parents but still possess great determination in their studies.

Parents motivate their students in a proper way. Educational attainment of students can be improved when proper advice and motivation to the children are provided (Malik \& Asif, 2012). Parents are well educated and have superior understanding on how to shatter a problem or know more effective motivational techniques they can help their children more productively (Chohan \& Khan, 2010). Students can perform better if they are rewarded and appreciated in their good did in school (Srivastava, 2018).

In the study, the researcher intends to know the levels and correlation between parental motivation and achievers of junior high and senior high. The study is very important in to gain knowledge and understanding for the researcher about the two variables especially parental motivation and achievement.

\section{2 Theoretical Background}

This study is supported by Deci and Ryan Self - determination theory proposed by Deci and Ryan in 1985. This theory is an empirical based of human motivation, development, and wellness. The theory focused in particular amount of motivation that shows different aspirations of people in their lives.

Deci and Ryan, (1985) said in their study of self - determination that all human beings have the fundamental needs to feel competent in order to develop and function optimally. This theory relates on how parents provide proper needs of motivation towards their children.

Many students have high and low achievements in their studies. They have different reason on how to get those achievements and one of the reasons is being motivated by their parents. Once the students are motivated they can build a strong desire in achieving their goals in life. Students become competent in school, willingness in their studies, and learning's can be improved.

In relation the theory of Deci and Ryan talks about the self - determination theory on how 
people shows their different motivation in life that has relationships to the study of parental motivation and achievers.

\subsection{Statement of Purpose}

The study intends to know the level of parental motivation of students and level of achievements of achievers, it also assess if there is a relationship between parental motivation and level of achievement.

\subsection{Review of Related Literature}

Parental motivation is defined as a motivation or an act given by the parents towards their children. It is important to motivate and encourage the children but not all the time that the motivation of parents is the reason why their children have a better achievement in school.

Students who are more inspired and under control of their parents have a better academic success (Atta \& Jamil, 2012). Parent with involvement to their children can affect the student attitude and behaviour including their achievement (McNeal, 2014). Parents with the highest level of intelligence will be transmitted to the student that can cause of greater achievement (Neha \& Shobhna, 2002). Parents who made a highest demand of encouragement can make the students anxiety and fear of failure (Koskie, 2014). It is not necessary to reject when parents give extrinsic rewards but it would be based when providing and receiving rewards become repetitive (Niu, 2016). Parental encouragement and academic achievement is significantly correlated to each other (Lawrence \& Barathi, 2016). The participation of parents through homework, providing a supportive home environment to learn, motivate and setting realistic expectations can improves efficiency (Mutodi \& Hlanganipai, 2014).The academic achievement of students can greatly enhances parents give care and different encouragement across all areas of social life (Igbo, Odu, Onu, \& Mezieobi, 2015). Higher autonomous motivation and less guided motivation of mother have been correlated with more positive effect during interaction and engagement (Grolnick, 2015).

Parents discuss with their children at home the importance of educational and educational actions which cause academic motivation (Safdar, Riasat, Saqib, Muhammad, \& Hukamdad, 2010). One of the most effective motivations is parental monitoring (Lowe \& Dotterer, 2013). Students can perform better when they are rewarded and appreciated by their academic achievements (Srivastava, 2014). When mother feel that parenting is productive they also motivated to communicate and support their student academics at home (Yamamoto, Holloway, \& Suzuki, 2016). Verbal responses is associated that it is very helpful and effective model to enhance the ability of the learner and they will be encourage also (Ghilay, Israel, \& Gilay, 2015).

High and low successful student both favor deep learning approach (Ahmed \& Ahmad, 2017). Students with high achievement showed high feeling of academic self - efficacy (Lavadores, Escobeda, \& Sosa, 2017). High achiever does not use any specific learning style in their studies (Kamarulzaman, 2013). Motivation for achievement has a significant effect on academic achievement among students (Rashmi \& Prasad, 2013). Students will be interested in the studies when they have high achievement score (Mewat, 2016). High achievers have 
the achievements because they have their own intrinsic motivation, decisions and efforts (Mahmood \& Manzoor, 2014). Academic achievements of achievers are in line with their intellectual ability (Khan \& Akhtar, 2002). Achievers that have a high need for accomplishment, positive expectation for progress, associate with a productive leader and wants intrinsic rewards if they success (Samia \& Mahmood, 2013). Even the students have poor support they still have a better commitment, effortful and have a high score in final exam (Nordmo \& Samara, 2009). The greatest predictors of the performance in school are academic learning and achievement (Salimabarka \& Anjun, 2017). Achievers have a good attitude, interested in the topic that being discussed and hard - working that leads them into achievements (Muhammad, Muhammad, Muhammad, \& Muhammad K, 2009). This is a stage in which students tend to act carelessly and often shows of immaturity (Gasco, Umali, Malabanan, \& Landicho, 2014). The STAD is an effective method to improve the achievement in different ability (Yaduvanshi \& Singh, 2019). Honor students oppose an activity which is boring or busy (Morris, 2005). To supply encouragement, parents tried to build on their children's academic abilities and past learning experiences. (Garn, Mattews, \& Jolly, 2010). Highly successful students have a strong belief towards compassion, charity, love and having a strong interest in education and learning (Bala, 2014).

\section{Research Method}

\subsection{Design}

This research used quantitative descriptive correlation design. It intends to determine the level of parental motivation and achievers level of achievements, and their association.

\subsection{Environment}

This study was conducted in Jagobiao National High School. The school consists of six buildings the four buildings for junior high and two buildings for senior high. The three buildings found at the upper part and other three buildings found at the lower part.

\subsection{Respondents}

The respondents are the achievers students of Jagobiao National High School. In grade 7 there are 8 sections namely; Joy, Hope, Love, Peace, Grace, Courage, Faith, and Justice. In grade 8 there are 7 sections namely; Humility, Honesty, Sincerity, Loyalty, Kindness, Patience, and Charity. In grade 9 there are 5 sections namely; Emerald, Opal, Onyx, Aquamarine and Ruby. In grade 10 there are 7 sections namely; Diamond, Topaz, Amethyst, Sapphire, Quartz, Jade and Amber. In grade 11 there are 5 strands namely; Humanities and Social Sciences (HUMSS), General Academic Strand (GAS), Accountancy Business and Management (ABM), Science Technology Engineering and Mathematics (STEM), and Technical Vocational Learning (TVL). In grade 12 there are 3 strands namely; Humanities and Social Sciences (HUMSS), Accountancy Business and Management (ABM), and General Academic Strand (GAS).

\subsection{Data Gathering Procedure}

The researcher needs to ask permission to the adviser of each section. When the permission 


\section{Macrothink}

International Journal of Social Science Research

ISSN 2327-5510 2020, Vol. 8, No. 2

was confirmed, the researcher would allow conduct survey. The respondents would answer in 2 or 5 minutes and the respondents would lead by questionnaire - checklist guide.

The data depend on the answer of the respondents. The answers of the respondents are the basis if there is correlation between Parental Motivation and Achievers.

\subsection{Instrument}

The main tool used in this study was questionnaire - checklist. It consists of two parts in questionnaire - checklist based on the two variables. Part 1 of the questionnaire - checklist can obtain the level of parental motivation to the students in presented 10 statements and the level of achievements towards honor students presented 10 situations. There are five checkboxes who made by the researcher and it was ranked as 5 - Always, 4 - Often, 3 Sometimes, 2 - Rarely, and 1 =- Never.

\section{Data Analysis and Discussion}

Table 1. Level of Parental Motivation

\begin{tabular}{|c|c|c|}
\hline Indicators & MW & Interpretation \\
\hline 1. My parents give advice when I have a problem & 3.61 & Often \\
\hline 2. My parents hug when I do well in school & 2.81 & Sometimes \\
\hline 3. My parents help me in doing my assignments & 2.8 & Sometimes \\
\hline 4. My parents ask me how's my day was going & 3.23 & Sometimes \\
\hline 5. My parents fell happy when I get awards & 3.73 & Often \\
\hline 6. My parents give time to jam with me & 3.46 & Often \\
\hline 7. My parents monitor my studies & 3.32 & Sometimes \\
\hline 8. My parents fell happy when I do my school tasks & 3.62 & Often \\
\hline 9. My parents congratulate me when I do well in school & 3.69 & Often \\
\hline 10. My parents give time to make my homework's & 3.55 & Often \\
\hline Overall Interpretation & 3.38 & Sometimes \\
\hline
\end{tabular}

SCALE: $1.00-1.80$ (never) 1.81-2.60 (rarely) 2.61-3.40 (sometimes) 3.41-4.20 (often) 4.20-5.00 (always)

The table 1 showed the average of weighted mean and interpretation of the first variable. Sometimes parents motivate them which have the overall interpretation of 3.38 average of weighted mean. The academic achievement of students can greatly enhance as parents give care and different encouragement across all areas of social life (Igbo, Odu, Onu, \& Mezieobi, 2015). Higher autonomous motivation and less guided motivation of mother have been correlated with more positive effect during interaction and engagement (Grolnick, 2015). One of the most effective motivations is parental monitoring (Lowe \& Dotterer, 2013). 
Table 2. Frequency of the levels of Parental Motivation

\begin{tabular}{lllll}
\hline & Frequency & Percent & Valid Percent & Cumulative Percent \\
\hline Not motivated & 1 & .7 & .7 & .7 \\
Slightly motivated & 8 & 5.5 & 5.5 & 6.2 \\
Fairly motivated & 37 & 25.5 & 25.5 & 31.7 \\
Motivated & 64 & 44.1 & 44.1 & 75.9 \\
Well-motivated & 35 & 24.1 & 24.1 & 100.0 \\
Total & 145 & 100.0 & 100.0 & \\
\hline
\end{tabular}

SCALE: 1.00 -1.80 (never) 1.81-2.60 (rarely) 2.61-3.40 (sometimes) 3.41-4.20 (often) 4.20-5.00 (always)

Out of 145 respondents there are many students are motivated by their parents with the frequency of 64 . There are also students who have fairly motivated by their parents that have a frequency of 37 . In addition, there has a frequency of 35 for those students who are well motivated by their parents. And there are also some students that slightly motivated and not motivated. It is not necessary to reject when parents give extrinsic rewards but it would be based when providing and receiving rewards become repetitive (Niu, 2016). One of the most effective motivations is parental monitoring (Lowe \& Dotterer, 2013). Parents tried to help their students based on their previous learning in school in order to build their children academic talents (Garn, Mattews, \& Jolly, 2010).

Table 3. Level of Achievement

\begin{tabular}{lll}
\hline Indicators & WM & Interpretation \\
\hline 1. I maintain my grades & 4.10 & Often \\
2. I perform extra - curricular activities & 3.81 & Often \\
3. I comply all my paper works & 4.06 & Often \\
4. I am happy when I arrived in school early & 4.19 & Often \\
5. I am responsible with the tasks given to me in school & 4.03 & Often \\
6. I achieved high scores in different tasks & 3.88 & Sometimes \\
7. I achieved certificate of recognition & 3.94 & Often \\
8. I am independent in doing my paper works & 4.06 & Often \\
9.My projects are well organized when I passed it & 3.92 & Often \\
10. I keep good attendance in class & 4.33 & Always \\
Overall Interpretation & 4.03 & Often \\
\hline
\end{tabular}

SCALE: $1.00-1.80$ (never) 1.81-2.60 (rarely) 2.61-3.40 (sometimes) 3.41-4.20 (often) 4.20-5.00 (always)

The table 3 presented level of achievers' achievement with the interpretation of each indicator. The overall weighted mean was 4.03 interpreted as often. It means that achievers are doing well in school. Most of them have high level of achievement in school but there are some also 
sometimes they achieve. Achievers that have a high need for accomplishment, positive expectation for progress, associate with a productive leader and wants intrinsic rewards if they success (Samia \& Mahmood, 2013). Highly successful students have a strong belief towards compassion, charity, love and having a strong interest in education and learning (Bala, 2014). Achievers have a good attitude, interested in the topic that being discussed and hard - working that leads them into achievements (Muhammad S., Muhammad B., Muhammad K., \& Muhammad K, 2009).

Table 4. Frequency of the level of Achievement

\begin{tabular}{lllll}
\hline & Frequency & Percent & Valid Percent & Cumulative Percent \\
\hline Fairly & 10 & 6.9 & 6.9 & 6.9 \\
Moderately & 49 & 33.8 & 33.8 & 40.7 \\
Always & 86 & 59.3 & 59.3 & 100.0 \\
\hline Total & 145 & 100.0 & 100.0 & \\
\hline
\end{tabular}

SCALE: $1.00-1.80$ (never) 1.81-2.60 (rarely) 2.61-3.40 (sometimes) 3.41-4.20 (often) 4.20-5.00 (always)

The table 4 showed that the achievers have always high achievements in school with the frequency of 86 which has a cumulative percent of 100. Some also students have moderately achievement with the frequency of 49. And also it has 10 frequencies for those students who have fairly achievement. High achievers have the achievements because they have their own intrinsic motivation, decisions and efforts (Mahmood, \& Manzoor, 2014). The student with high score in achievement shows high degree of interest in the studies (Mewat, 2016). Academic achievements of achievers are in line with their intellectual ability (Khan \& Akhtar, 2002).

Table 5. Cross tabulation of Parental Motivation and Achievements

\begin{tabular}{|c|c|c|c|c|c|}
\hline \multicolumn{6}{|c|}{ Level of Achievement } \\
\hline \multirow{6}{*}{$\begin{array}{l}\text { Parental } \\
\text { Motivation }\end{array}$} & \multirow{3}{*}{$\begin{array}{l}\text { Not motivated at all } \\
\text { Slightly motivated }\end{array}$} & \multirow{2}{*}{$\begin{array}{l}\text { Moderate Effort } \\
\text { of Achieving } \\
0\end{array}$} & \multirow{2}{*}{$\begin{array}{l}\text { Adequate Effort } \\
\text { of Achieving } \\
0\end{array}$} & \multicolumn{2}{|l|}{$\begin{array}{l}\text { With Extra Effort } \\
\text { of Achieving }\end{array}$} \\
\hline & & & & 1 & 1 \\
\hline & & 0 & 3 & 5 & 8 \\
\hline & Fairly motivated & 6 & 19 & 12 & 37 \\
\hline & Moderately motivated & 4 & 23 & 37 & 64 \\
\hline & Well-motivated & 0 & 4 & 31 & 35 \\
\hline Total & & 10 & 49 & 86 & 145 \\
\hline
\end{tabular}

SCALE: $1.00-1.80$ (never) 1.81-2.60 (rarely) 2.61-3.40 (sometimes) 3.41-4.20 (often) 4.20-5.00 (always) 


\section{Mll Macrothink}

International Journal of Social Science Research

ISSN 2327-5510

2020, Vol. 8, No. 2

The table 5 presented a cross tabulation in parental motivation and achievement. It was presented that there are more student who involve by their parents' motivation which is the total of 64 . Second has the total of 37 which is fairly motivated. Third has the total of 35 which is achievers are well - motivated. Fourth, has the total of 8 which is slightly motivated while the fifth has the total of 1 which is not motivated. Furthermore, there are total of 10 for those who have a moderate effort of achieving, 49 achievers who have an adequate effort of achieving and 86 respondents who have an extra effort of achieving. Most of the respondents are concentrated in the middle of the table. That is, more respondents manifest either fairly motivated or well-motivated attitudes towards moderately and always higher level of achievement. Students can perform better when they are rewarded and appreciated by their academic achievements (Srivastava, 2014). Parental encouragement and academic achievement is significantly correlated to each other (Lawrence \& Barathi, 2016).Achievers have a good attitude, interested in the topic that being discussed and hard - working that leads them to achieve and consider that their studies can do them good (Muhammad, Muhammad, Muhammad, \& Muhammad, 2009).

Table 6. Chi-Square Tests of Parental Motivation and Achievements

\begin{tabular}{llll}
\hline & Value & df & Asymp. Sig. (2-sided) \\
\hline Pearson Chi-Square & $26.623^{\mathrm{a}}$ & 8 & .001 \\
Likelihood Ratio & 30.207 & 8 & .000 \\
Linear-by-Linear Association & 12.342 & 1 & .000 \\
N of Valid Cases & 145 & & \\
\hline
\end{tabular}

SCALE: $1.00-1.80$ (never) 1.81-2.60 (rarely) 2.61-3.40 (sometimes) 3.41-4.20 (often) 4.20-5.00 (always)

The table 6 describe that the $p$ value (.001) is less than the standard alpha value (.05). There is a significant association between parental motivation and achievements. Parents with the highest level of intelligence will be transmitted to the student that can cause of greater achievement (Neha \& Shobhna, 2002). Parent-child involvement practices can influence their attitudes and achievements of students (Mc Neal, 2014). Even the students have poor support they still have a better commitment, effortful and have a high score in final exam (Nordmo \& Samara, 2009).

\section{Findings}

In the study the data presented that the level of parental motivation is sometimes they provide to their students. There are times that their parents give a motivation and sometimes also parents give motivation to them. However, students are still motivated by their parents but not all the time.

Furthermore, the achievements of achievers are still in high level. They are very determined and persistent in their studies. They do well in school even though they are not always 
motivated by their parents but they are motivated by their own achievements.

In addition, the value of parental motivation is less than the value of achievement. Therefore, the level of achievements of students does not rely on their parents' motivation. However, the result is that parental motivation and achievement has significant association.

\section{Conclusion}

There is a relationship between parental motivation and achievements. It was revealed that parents promote high level of motivation to their students should have more achievements in their studies, but students without motivation from their parents have poor achievements. However, there are some chances that the achievements of students can be based in their own motivation or intrinsic motivation. It means that they are determined enough to be successful even if they don't have motivation from their parents. Through their accomplishment they became energetic to perform well in school which may lead them into achievements. When achievers having instant achievements in school their parents also motivated to give an encouragement, moral support, guidance and proper motivation for them to achieve it. In contrary, motivation which comes from the parents is very essential and meaningful towards the students, because they are the first foundation of their children in different aspects in life.

\section{Recommendation}

These are the recommendation which can help us of what are the things that are needed to do regardless with this study.

Students should not always rely on their parents they must teach themselves to stand on their own feet because parents aren't always there to motivate us or support us.

Parents must provide a proper motivation to their students. They could make a strategies or something rewards for their students in order for them to be more motivated which can help them to have a better achievement in their studies.

Teachers should also provide a proper motivation to their students just like advised and teach them on how to overcome different challenges in life.

\section{References}

Acharya, N., \& Joshi, S. (2009). Influence of Parent's Education on Achievement Motivation of Adolescent. Indian Journal Social Science Researches, 6(1), 72-79. Retrieved from https://www.researchgate.net/profile/Rakesh_Pandey13/publication/224922611_Hemispheric _Asymmetry_in_Depression_An_Overview/links/09e4150ddf1673e59f000000.pdf\#page=7

Ahmed, A., \& Ahmad, N. (2017). Comparative Analysis of Rote Learning on High and Low Achievers in Graduate and Undergraduate Programs. Journal of Education and Educational Development, 4(1), 111-125. https://doi.org/10.22555/joeed.v4i1.982

Atta, M. A., \& Jamil, A. (2012). Effects of Motivation and Parental Influence on the Educational Attainments of students at secondary Level. Academic Research International, 2(3). 
http://www.savap.org.pk/journals/ARInt./Vol.2\%283\%29/2012\%282.3-52\%29.pdf

Bala, R. (2014). Values and Adjustment Problems of High Achievers. International Journal of Educational Planning \& Administration, 4(2), 113-118.Retrieved from https://www.ripublication.com/ijepa/ijepav4n2_02.pdf

Chohan, B. I., \& Khan, R. M. (2010). Impact of Parental Support on the Academic Performance and Self Concept of the Student. Journal of Research and Reflections in Education, 4(1), 14-26. Retrieved from https://www.researchgate.net/publication/216035869_Impact_of_Parental_Support_on_the_ Academic_Performance_and_Self_Concept_of_the_Student/link/0c96052a872c37e25500000 0/download

Deci, E. L., \& Ryan, R. M. (2000). Self-Determination Theory and the Facilitation of Intrinsic Motivation, Social Development, and Well-Being. American Psychologist, 55(1), 68-78. https://doi.org/10.1037/0003-066X.55.1.68

Garn, A. C., Matthews, M. S., \& Jolly, J. L. (2010). Parental Influence on the Academic Motivation of Gifted Students: A Self-Determination Theory Perspective. Gifted Child Quarterly, 54(4). https://doi.org/10.1177/0016986210377657

Gasco, Z. L., Umali, L. M. D., Malabanan, M. G. A., \& Landicho, L. C. (2014). Perfectionism and well-being among Academic Achievers. Asia Pacifis Journal of Education, Arts and Sciences, $3 . \quad$ Retrieved from http://apjeas.apjmr.com/wp-content/uploads/2014/07/APJEAS-2014-1-050.pdf

Ghilay, Y., Israel, H., \& Ghilay, R. (2015). PISMS: Parental Influence of Student Motivation and Self- esteem in Primary Education. Journal of Studies in Education, 5(4). https://doi.org/10.5296/jse.v5i4.8510

Grolnick, W. (2015). Mothers' Motivation for Involvement in their Children Schooling: mechanisms and outcomes. Motivemot, 63-73. https://doi.org/10.1007/s11031-014-9423-4

Igbo, J. N., Odo, A. S., Onu, V. C., \& Mezieobi, D. (2015). Parent-child Relationship Motivation to Learn and Students Academic Achievement in Mathematics. IMPACT: International Journal of Research in Applied, 3(9), 87-108. Retrieved from http://oaji.net/articles/2015/491-1444304021.pdf

Jabeen, S., \& Khan, M. N. (2013). A Study on Need Achievement of High and Low Achievers. Journal of Education and Practice, 4(4). Retrieved from https://pdfs.semanticscholar.org/ea91/7837b97dcc7759b9247047cf12340c9dfb75.pdf

Kamarulzaman, W. (2013). High Achievers Learning style: A case Study of a Student on the president's list at a Public University. SSRN, 55. https://doi.org/10.2139/ssrn.2189177

Khan, M. A., \& Akhtar, F. (2002). Adjustment Problems of Gifted Achievers and Underachievers. Journal of Applied Research in Education. Retrieved from file://C:/Users/dasdefsefefeww\%20dawda/Downloads/ADJTUSTMENTPROBLEMSOFGIF TEDACHIEVERSANDUINDERACHIEVERS.pdf 
Koskei, B. K. (2014). Infleunce of Parental Involvement on Students Academic Performance of Public Mixed Day Secondary Schools in Kuresoi Sub-country, Nakuru country, Kenya. International Journal of Education and Research, 2(12). Retrieved from https://www.ijern.com/journal/2014/December-2014/42.pdf

Lavadores, A. K. C., Escobedo, P. S., \& Sosa, J. P. (2017). Academic Self- efficacy of High Achieving students in Mexico. Journal of Curriculum and Teaching, 6(2), 84-89. https://doi.org/10.5430/jct.v6n2p84

Lawrence, A. S., \& Barathi, C. (2016). Parental encouragement in relation to academic achievements of higher secondary school students. IJARIIE, 2. Retrieved from https://files.eric.ed.gov/fulltext/ED571491.pdf

Lowe, K., \& Dotterer, A. M. (2009). Parental Monitoring, Parental Warmth and Minority Youths' Academic. Outcomes: Exploring the Integrative Model of Parenting. Journal in Youth and Adolescence.

Mahmood, A. K., \& Manzoor, A. R. (2014). Locus of Control of High and Low Achivers. Journal of Applied Research in Education, 18 \& 19(1). Retrieved from file://C:/Users/dasdefsefefeww\%20dawda/Downloads/LOCUSOFCONTROLOFHIGHAND LOWACHIEVERS.pdf

McNeal, Jr. R. B. (2014). Parent Involvement, Academic Achievement and the Role of Students Attitude and Behaviors as Mediators. Universal Journal of Educational Research, 2(8), 564-576.

Mewat, H. (2016). Factors Affecting the Academic Achievement: A Study of Elementary School Students of NCR Delhi, India. Journal of Education and Practice, 7(4). Retrieved from https://files.eric.ed.gov/fulltext/EJ1092343.pdf

Morris, M. (2005). Two Sides of the Communicative Coin: Honors and Non honors French and Spanish classes in a Midwestern High School. Foreign Language Annals, 38(2), 237-249. https://doi.org/10.1111/j.1944-9720.2005.tb02488.x

Muhammad, S., Muhammad, B., Muhammad, N. K., \& Muhammad, S. K. (2009). Study orientation of High and Low Academic Achievers at Secondary Level in Pakistan. Academic Journals, 4(4), 204-207. Retrieved from http://www.academicjournals.org/app/webroot/article/article1379606785_Sarwar\%20et\%20al .pdf

Mutodi, P., \& Hlangnipai, N. (2014). The Impact of Parental Involvement on Student Performance: A Case Study of a South African Secondary School. Mediterranean Journal of Social Science, 5(8). https://doi.org/10.5901/mjss.2014.v5n8p279

Nordmo, I., \& Samara, A. (2009). The Study experience of the High Achievers in a competitive Academic environment: A cost of success. Issues in Educational Research, 19(3). Retrieved from http://www.iier.org.au/iier19/nordmo.pdf

Nui, L. (2016). Parental Motivational Practice, Parent Involvement, and Students' Choice of 
Study Field in College. World Journal of Education, 6(5). https://doi.org/10.5430/wje.v6n5p36

Rashmi, \& Prasad, B. (2013). Effect of Achievement Motivation on High and Low Achievers of Secondary School Students: A Comparative Study. IJBAR, 2, 133-135. Retrieved from https://www.academia.edu/5191818/Effect_of_Achievement_Motivation_on_High_and_Low _Achievers_of_Secondary_School_Students_A_Comparative_Study

Safdar, R. G., Riasat, A., Saqib, S., Muhammad, S. K., \& Hukamdad. (2010). Parental Involvement in Children Academic Motivation. Asian Social Science, 6(4). https://doi.org/10.5539/ass.v6n4p93

Salimabarkat, A., \& Anjun, A. (2013). Intelligence as a determinant of Academic achievement: A Comparative Study of high achievers and low-achievers. International Journal of Humanities and Social Sciences, 6, 79-88. Retrieved from file://C:/Users/dasdefsefefeww\%20dawda/Downloads/2-72-1510311809-9.Abs\%20\%20IJH SS\%20-\%20INTELLIGENCE\%20AS\%20A\%20DETERMINANT\%20OF\%20ACADEMIC $\% 20$ ACHIEVEMENT-IASET.pdf

Srivastava, S. (2018). Impact of Motivation on Management Students' Academic Performance in Relation to Overall Advancement. International Journal of Advance Research, Ideas and Innovations in Technology, 4, 214-217. Retrieved from https://pdfs.semanticscholar.org/cd2c/d726ab604e1632f844ad4c6a92a1fd98b913.pdf

Yaduvanshi, S., \& Sigh, S. (2019). Fostering Achievement of Low - Average and High Achievers in Biology through Structured Cooperative Learning STAD method. Education Research International. https://doi.org/10.1155/2019/1462179

Yamamoto, Y., Holloway, S. D., \& Suzuki, S. (2016). Parental Engagement in children's education: Motivating Factors in Japan and the U.S. School Community Journals, 26(1). Retrieved from file://C:/Users/dasdefsefefeww\%20dawda/Downloads/YamamotoHollowaySuzuki.pd

\section{Glossary}

Parental motivation: is an act given by the parents towards their students to make them work harder in their students.

Achievers: are the students who received awards like medals and certificates in their school usually as a result of their efforts, handwork's, and determination.

Achievement: it is a state of being successfully, typically by effort, courage, or skill.

\section{Appendix}

Appendix 1. Survey Questionnaire Parental Motivation and Achievement

\section{TOOL: CHECKLIST}




\section{Macrothink}

International Journal of Social Science Research

ISSN 2327-5510

2020, Vol. 8, No. 2

Directions: Answer the questionnaire in the following statements below. Closed your answer based on your experience.

\section{5- Always 4 -Often 3 -Sometimes 2 -Rarely 1 -Never}

\begin{tabular}{llllll}
\hline PART I Parental motivation & 5 & 4 & 3 & 2 & 1
\end{tabular}

1. My parents give advice when I have a problem

2. My parents hug when I do well in school

3. My parents help me in doing my assignments

4. My parents ask me how's my day was going

5.My parents fell happy when I get awards

6. My parents give time to jam with me

7. My parents monitor my studies

8.My parents fell happy when I do my school tasks

9. My parents congratulate me when I do well in school

10. My parents give time to make my homework's

\begin{tabular}{l}
\hline PART II Achievers level of achievements \\
\hline 1. I maintain my grades \\
2. I performed extra - curricular activities \\
3. I comply all my paper works \\
4. I am happy when I arrived in school early \\
5. I am responsible with the tasks given to me in school \\
6. I achieved high scores in different tasks \\
7. I achieved certificate of recognition \\
8. I am independent in doing my paper works \\
9. My projects are well organized when I passed it \\
10. I keep a good attendance in class
\end{tabular}

\section{Copyrights}

Copyright for this article is retained by the author(s), with first publication rights granted to the journal.

This is an open-access article distributed under the terms and conditions of the Creative Commons Attribution license (http://creativecommons.org/licenses/by/4.0/). 